\title{
A Website Evaluation Of Travel Agencies IN IRAN: AN ADOPTION LEVEL AND VALUE CREATION APPROACH
}

\author{
Raika Sadeghein ${ }^{1}$, Farid Khoshalhan ${ }^{2}$ and Sajad Homayoun ${ }^{3}$ \\ IT Group, Department of Industrial Engineering, K. N. Toosi University of Technology, \\ Tehran, Iran \\ r_sadeghein@yahoo.com \\ khoshalhan@kntu.ac.ir \\ sajadhomayoun@gmail.com
}

\begin{abstract}
Nowadays e-commerce is playing a big role in the tourism industry. It is safe to say that tourism industry is one of the only industries that accepted e-commerce with open arms. Travel agencies are one of the first organizations to move toward joining the online environment. Information technology has changed this industry in a way that travellers can now plan, reserve and purchase their ideal trips in a fraction of time and money used by traditional methods. This research focuses on investigating travel agencies websites in Iran to see where they are standing today according to the stages of internet adoption. In addition this paper aimed to evaluate the performance of the travel agencies in the online environment. The main weaknesses were extracted to help managers enhance their e-commerce activities in Iran's tourism. The value creation and capturing concepts were introduced, and it was concluded that perhaps the most serious disadvantage of the travel agencies websites in Iran, is that they did create value but they did not facilitate value capturing.
\end{abstract}

\section{KEYWORDS}

e-commerce; e-tourism; website evaluation; internet adoption

\section{INTRODUCTION}

Internet has combined most features of the existing media and interactivity, as a result not only individual's business models have changed but also it has changed the traditional social structure. Today millions of people around the world use the internet for purposes such as data mining, learning, entertainment, shopping, etc. with the extensive use of internet, the foundation of business models have altered and the market is leaning towards e-business models.

Since the emersion of internet, travel planning (e.g. searching for travel information and reservation) has always been one of the main reasons that people use the internet. In 2007, the top 5 things to be sold online in US included books, clothes, travel arrangements, gifts and CDs. [1]

Travel and tourism generate approximately $11 \%$ of the worldwide GDP, which could be a big contribution to a country's income. UNWTO forecasted that the number of tourists around the world would reach 8.1 billion by the year 2030[2]. Travel agencies are one of the most effective elements of the tourism industry, and their success has a significant impact on tourism growth. Today, in order to succeed in this industry, organizations have to utilize the potentials of the DOI : $10.5121 /$ ijait.2012.2601 
International Journal of Advanced Information Technology (IJAIT) Vol. 2, No.6, December 2012

internet, therefore web presence is inevitable. Considering the substantial characteristic of the internet such as cost reduction, increase in productivity and efficiency and also having broader access to potential customers, travel agencies have initiated providing services through their websites. A means to achieve sustainable competitive advantage for tourism organizations is having superior web service quality. Forester research implies that weak website design will result in 50\% loss of organizations' potential sales which is due to customers not finding what they are looking for. It also causes losing $40 \%$ repeated website visits which are a result of users' negative first experiences [3].

Unfortunately despite Iran's high historical, natural and cultural tourism potential, its income from this industry is insignificant, although there are great opportunities for improvement. A reason could be the low rate of internet usage amongst Iranian people in comparison with people from more developed countries. However the increase in Iran's internet usage in recent years has been considerable and it is expected to reach a credible number in a few years. In 2011 the number of internet users in Iran has been 36.5 million which is 146 times more than the year 2000 (only 250000 users). This number is comprehensive for Iran because it is $50.3 \%$ of the users in Middle East. According to the statistics [4] internet penetration rate in Iran is $46.9 \%$ compared to the world's average penetration rate which is $30.2 \%$.

Website's electronic service quality could also be a cause of Iran's low income from this industry. Considering this issue, in this paper the tourism websites have been evaluated with the objective of determining their web presence stage and some of their weaknesses has been discovered.

\section{Literature REVIEW}

Most studies in the e-commerce website evaluation field focused on e-commerce websites in general. Very few researchers investigated e-tourism websites criteria and specially travel agencies websites. Chio et al. $[4,5]$ published a paper in which they analyzed 83 papers from 23 different journals to review the complete literature in e-commerce website evaluation; they have also proposed a technical e-commerce website evaluation method containing their mentioned criteria in their previous study [6].

Xiaobing et al. [7], have also proposed criteria and a method for e-commerce website evaluation and ranking. They have ranked the websites according to helping customers in choosing the best product, service or information. Cao et al. [8] proposed a model based on AHP and grey evaluation. They have presented technical, commercial and security and privacy criteria for an organization's website evaluation. Soyoung and Lesli [9], have considered website appearance, entertainment, useful information, transaction possibility, response time and trust as website evaluation criteria. They measured these criteria with having customer satisfaction in mind. Alastair [10], has studied the e-government website evaluation criteria in New Zealand. He mentions that it is important for websites to provide orientation information and privacy and security consideration, the printed documents should be converted to electronic versions, resources must be up to date, metadata should be used effectively, pages must be accessible for disabled users and also helpful information should be available for search engines. He proposed to categories of criteria, information content criteria and ease of use criteria. Nocolae-george [11] has introduced tools and criteria for website quality evaluation, and also investigated the concepts of information evaluation and process evaluation. Hasan et al., [12] have explored previous papers in the website evaluation field in order to propose general criteria for website quality evaluation regardless of the type of service they provide. They have considered 4 criteria which include content quality, design quality, organizational quality and user friendliness. Bilsel et al., [13] have evaluated and ranked hospital websites. Hung et al., [14] have presented an ecommerce website evaluation form. The goal of their evaluation was the ease of discovering 
desirable websites from numerous websites and also accessibility of the wanted services and products. Bindu Madhuri et al., [15] have combined Grey clustering theory and AHP for website evaluation. They used the website logs for their assessment.

Painter and Satitkit [16], have investigated 30 travel agencies in New Zealand and have proposed a model for website evaluation consisting of information, transaction services, promotion, trust, other information and non-functional requirements. Chung and Law [17], presented a conceptual framework for evaluating hotels websites performance. Park [18] has investigated criteria such as availability of online reservation, tourism information, interactive communication tools, product search engine, etc in 23 travel agencies in Korea. Law and Leung [19], have evaluated online reservation services in airlines. Maswera et al., [20] after reviewing the literature of tourism website evaluation until 2007, have proposed a model for tourism website evaluation. In their model the evaluation criteria are categorized in 6 groups, corporate information, products information, non-product information, CRM, reservation and payment.

After exploring the previous papers in the website evaluation field, the criteria have been chosen considering the e-tourism domain and its characteristics. It is worthy to mention that in the criteria selection, Iran's attitude towards the internet and governmental limitations were considered for example famous social networks like Facebook are banned in Iran, so the criteria related to social networks are ignored.

However, having an advanced website, will not always lead to an organization's success. Today organizations are continuing to work under the increasing pressure of the business world. The three main pressures include: competition, consumer and change, the three Cs [21]. In such environment, organizations must put an extra effort in attracting and retaining customers in order to gain competitive advantage. One of threats of the online environment is being imitated. For this reason, organizations must pay more attention to value creation. They must try to create significant and unique values for the customers. Though, creating value is not enough for achieving a sustainable competitive advantage. an additional item that should considered is how to capture that value in form of profit. One of the reasons of the failure of many e-commerce websites is their lack of ability to capture the value they have created [22].

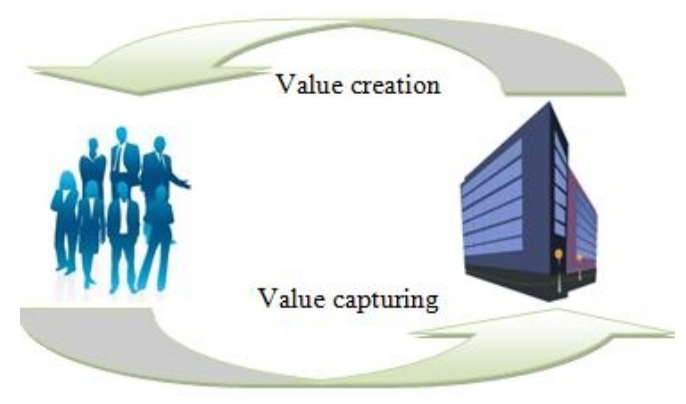

Figure 1. The value creation and capturing concept

\section{The Proposed Framework For Website Evaluation In IRANIAN TRAVEL AGENCIES}

The proposed framework has been designed according to the tourism needs in Iran. This model is based on the model proposed by Maswera et al. [20]. Many researchers have tried to improve this model; saddad [23] is one of them. In the present paper Maswera's model [20] is combined with 
International Journal of Advanced Information Technology (IJAIT) Vol. 2, No.6, December 2012

the model proposed by Chiou et al. [5]. The criteria selection process has been done with having the Iranian travel agencies and their current level of activities in mind.

The importance of this model is its criteria integration in the website evaluation of Iranian travel agencies which could benefit the agency's managers in improving their internet based service qualities.

A. Chosen criteria for evaluating travel agencies

A checklist of the criteria chosen for evaluation of websites was prepared. The websites were evaluated according to the checklist, and the results were analyzed.

Here are the criteria:

Company overview: an overall description of the agency, its management, its license, time of foundation, etc.

News: corporate news and everything new which is happening in relation with the agency. Employment opportunities: mentioning the empty positions in the organization in order to find the appropriate people to fill the position.

Investors and community relations: relationship with suppliers, partners, etc.

Product description: an explanation of the product/ services details.

Rates/Fares: prices charged for products/ services.

Product/Price comparison: comparing products or services and their costs.

Price details: price transparency (i.e. knowing how much each part of your order cost e.g. the ticket, the hotel, etc.)

Product search: simple search of the products.

Product variety: different products/services (e.g. having different options for the same destination)

Photo gallery: availability of pictures of the destinations, so the customers can make better decisions.

Hierarchical product category: hierarchical categorization of services/products for easier access (e.g. dividing tour packages into internal and external tours)

Interactivity: the ability of users to communicate with the website and get answers (e.g. online chat, online polling, etc.)

FAQ: most frequent questions of the users about the website, services or products and their answers.

Order list: a list of all the products/services ordered by the customer.

Weather/climate: facilitating the possibility of users to know the weather of the destination.

Other places to see/visit: nearest tourist attractions to the destination.

Searching mechanism: a mechanism for searching the website content.

Language usability: showing the content of the website in different languages. 
International Journal of Advanced Information Technology (IJAIT) Vol. 2, No.6, December 2012

Contact details: information necessary for contacting the agency (e.g. address, phone number, etc.)

Promotions and special offers: products/services with especially low prices.

Customized offering: special offers customized for each individual.

Member community: community consist of users talking about different products/services.

E-newsletter: sending information about new products, services and news via e-mail.

Loyalty systems: offering special products/ services to loyal customers with the purpose of retaining them.

Mail to friend button: the possibility to send some of the website content to the users' friends in order to introduce services/products.

Customer profiling: saving customer information and creating user profiles so that the products, services and information can be customized.

Customized content: the content presented to each user is tailored to fit his/her characteristics.

Privacy and security: clear laws for protecting customers' rights and information privacy.

Checking ticket/accommodation reservation: being able to check for vacancies.

Ticket/accommodation reservation: the possibility of reserving ticket/ accommodation online.

Tracking reservation: being able to track the status of your reservation.

Cancelation policy: policies and laws dealing with cancelation of reservation or purchase.

Amending reservation: the ability to change the reserved or purchased product/ service.

Debit/credit card: the ability to pay online with credit or debit card.

Currency convertor: presentation of exchange rate real time (i.e. with every slight change in the market the data should be updated)

The evaluation results are shown in table 1 . 
International Journal of Advanced Information Technology (IJAIT) Vol. 2, No.6, December 2012

Table 1. The results of website evaluation process

\begin{tabular}{|c|c|c|}
\hline Evaluation criteria & Number ${ }^{*}$ & $\%^{*=1}$ \\
\hline \multicolumn{3}{|c|}{ Corporate information } \\
\hline Company overview & 42 & 77 \\
\hline CEO message & 2 & 4 \\
\hline Financial report & 0 & 0 \\
\hline News & 18 & 33 \\
\hline Employment opportunities & 3 & 5 \\
\hline Investor \& Community relations & 5 & 9 \\
\hline \multicolumn{3}{|c|}{ Product Information } \\
\hline Product description & 44 & 81 \\
\hline Rates/fares & 38 & 70 \\
\hline Product/Price comparison & 36 & 66 \\
\hline Price details & 3 & 5 \\
\hline Product search & 14 & 26 \\
\hline Product variety & 36 & 66 \\
\hline Photo gallery & 20 & 37 \\
\hline Hierarchical product category & 25 & 46 \\
\hline Interactivity & 19 & 35 \\
\hline FAQs & 5 & 9 \\
\hline Order list & 3 & 5 \\
\hline \multicolumn{3}{|c|}{ Non-Product Information } \\
\hline Weather/Climate & 18 & 33 \\
\hline Other places to visit & 6 & 11 \\
\hline Searching mechanism & 15 & 28 \\
\hline Language usability & 18 & 33 \\
\hline \multicolumn{3}{|c|}{ CRM(Customer Relationship Management) } \\
\hline Contact details including directions & 50 & 92 \\
\hline Email address & 44 & 81 \\
\hline Promotions and special offers & 9 & 16 \\
\hline Customize offering & 1 & 2 \\
\hline Member community & 0 & 0 \\
\hline E-news letter & 13 & 24 \\
\hline Loyalty systems & 2 & 4 \\
\hline Customer profiling & 12 & 22 \\
\hline Customized content & 0 & 0 \\
\hline Privacy and security & 0 & 0 \\
\hline \multicolumn{3}{|c|}{ Reservation } \\
\hline \multicolumn{3}{|c|}{ Accommodation reservation } \\
\hline Checking availability & 0 & 0 \\
\hline Making online reservations & 1 & 2 \\
\hline Tracking reservations & 1 & 2 \\
\hline Cancelation policy & 0 & 0 \\
\hline Amending reservations & 0 & 0 \\
\hline \multicolumn{3}{|c|}{ Ticket reservation } \\
\hline Checking availability & 3 & 5 \\
\hline Making online reservations & 4 & 7 \\
\hline Tracking reservations & 3 & 5 \\
\hline Cancelation policy & 0 & 0 \\
\hline Amending reservations & 0 & 0 \\
\hline
\end{tabular}


International Journal of Advanced Information Technology (IJAIT) Vol. 2, No.6, December 2012

Table 1. The results of website evaluation process (continue)

\begin{tabular}{|c|c|c|}
\hline Evaluation criteria & Number * & $\%^{* * 1}$ \\
\hline \multicolumn{3}{|c|}{ Payment } \\
\hline Credit card & 0 & 0 \\
\hline Debit card & 6 & 11 \\
\hline Currency convertor & 5 & 9 \\
\hline
\end{tabular}

*Number of websites that have met the criteria requirement

$* *$ Percentage of the websites that have met the criteria requirements

\section{RESEARCH IMPLICATION}

According to Jelassi [22] a perspective on assessing current usage of the Internet channel is to assess the current level of Internet services and integration of Internet marketing with other marketing activities. Stage models of capability delivered through the online presence assist in this evaluation. Companies that operate in a particular market tend to follow a natural progression in developing their web site to support their marketing activities. Teo and Pian [24] have proposed a framework which classifies web presence into 5 levels (see table 2).

According to Teo and Pian [24] in level 1 of the website presence, websites are used as catalogues, which means in addition to level 0 features they must contain product description and rates. In Iran $81 \%$ of travel agencies provided product description and $70 \%$ rates/fares.

According to the results, only $26 \%$ of the websites were successful in implementing product search and $28 \%$ in searching mechanism, which are both necessities of level 2.

For e-tourism websites one of the essential criteria for being in level 2 is checking availability of products such as ticket, accommodation, and etc. unfortunately only $5 \%$ of the websites possessed checking ticket availability and none of them possessed checking accommodation availability.

As a result according to the specifications for different levels of web presence, it can be concluded that the Iranian websites could not implement all the expected criteria in level 2.

In level 3 websites should facilitate interactivity and financial transactions in form of e-payment. Unexpectedly results show that the percentage of interactivity and financial transactions are more than checking availability of products, which implies that travel agencies managers in Iran do not have a proper understanding of the internet presence strategies, because without completing the previous levels, they have entered the new one.

In level 4, the concept of customization and personalization is introduced. Content customization, offering and call back services are this level's criteria. According to the results none of the websites have entered this level.

In this paper 292 travel agencies have been investigated according to the chosen criteria, from which 170 agencies were located in Tehran (the capital of Iran), and 122 were located in other cities. The results are presented in Table 1.

As it is shown in Table 1, 92\% of the evaluated websites provided contact details, and this criterion scored the highest percentage among other criteria. Also $81 \%$ of the websites contained e-mail addresses, although the expected percentages for both criteria were $100 \%$. One of the 
International Journal of Advanced Information Technology (IJAIT) Vol. 2, No.6, December 2012

necessities of internet presence even in the lowest levels is providing information for contacting the firm.

Table 2. Internet adoption levels

\begin{tabular}{|c|c|c|}
\hline $\begin{array}{l}\text { Level of Internet } \\
\text { Adoption }\end{array}$ & Online Development & Strategic Contribution \\
\hline $\begin{array}{l}\text { Level } 0 \text { - e-mail } \\
\text { adoption }\end{array}$ & $\begin{array}{l}\text { e-mail account(s) but no web } \\
\text { site }\end{array}$ & $\begin{array}{l}\text { Limited to Internet and Intra- } \\
\text { organisational communications } \\
\text { Very limited resource implications. }\end{array}$ \\
\hline $\begin{array}{l}\text { Level } 1 \text { - } \\
\text { Internet presence }\end{array}$ & $\begin{array}{l}\text { Occupying a domain name or } \\
\text { simple web sites providing } \\
\text { mainly company information } \\
\text { and brochures, therefore tending } \\
\text { to be static content and non- } \\
\text { strategic in nature. }\end{array}$ & $\begin{array}{l}\text { Initial Internet presence. } \\
\text { At this stage experimentation is taking } \\
\text { place to build skill/ knowledge base. } \\
\text { Practically, implementation of } \\
\text { technology is still in progress. Limited } \\
\text { resource implications. }\end{array}$ \\
\hline $\begin{array}{l}\text { Level 2- } \\
\text { prospecting }\end{array}$ & $\begin{array}{l}\text { Web sites provide customers } \\
\text { with company information, } \\
\text { product information (as level 1) } \\
\text { plus news, events, interactive } \\
\text { content, personalized content, e- } \\
\text { mail support, and simple search. }\end{array}$ & $\begin{array}{l}\text { Prospecting. } \\
\text { At this point growth and development } \\
\text { begins - providing potential customers } \\
\text { with access to the products with } \\
\text { minimal information - distributing } \\
\text { cost.Growing resource implication. }\end{array}$ \\
\hline $\begin{array}{l}\text { Level } 3- \\
\text { business } \\
\text { Integration }\end{array}$ & $\begin{array}{l}\text { Web sites at this level are more } \\
\text { complex with added features for } \\
\text { interactive marketing, sales } \\
\text { ordering, online communities } \\
\text { and secure transactions. Also } \\
\text { includes more sophisticated } \\
\text { versions of features found in } \\
\text { level } 1 \text { and } 2 \text {, e.g. more } \\
\text { comprehensive information and } \\
\text { search facilities. }\end{array}$ & $\begin{array}{l}\text { Integration. } \\
\text { At this point integration begins to pull } \\
\text { together business processes and } \\
\text { business models. Internet strategy } \\
\text { becomes interlinked with a firm's } \\
\text { business strategy. Business support, as } \\
\text { well as cross- functional links between } \\
\text { customers and suppliers are developing. }\end{array}$ \\
\hline $\begin{array}{l}\text { Level 4- } \\
\text { business } \\
\text { transaction }\end{array}$ & $\begin{array}{l}\text { At this level the Internet- based } \\
\text { activities are central to the } \\
\text { organization, transforming the } \\
\text { overall business model } \\
\text { throughout the organisation. }\end{array}$ & $\begin{array}{l}\text { Transformation. } \\
\text { At this level transformation starts to } \\
\text { take place. Internet - based operations } \\
\text { shape the organisation's business } \\
\text { strategies and are used to focus on } \\
\text { building relationships and seeking new } \\
\text { business opportunities. }\end{array}$ \\
\hline
\end{tabular}


In general it can be deduced that most of the travel agencies in Iran are at level 1 of the web presence and a few have entered level 2.

As can be seen in figure 2, 63\% of the travel agencies in Tehran have realized the importance of using the internet as a new channel for sales, marketing, advertising, etc. but only $36.3 \%$ have really entered the internet which means the other $73.4 \%$, even with the knowledge of the importance of web presence, either could not succeed in entering the web or have previously entered the web but failed. The same thing applies to other cities; in 122 evaluated agencies, 106 claimed to have web presence, but only 14 out of 106 agencies had active websites.

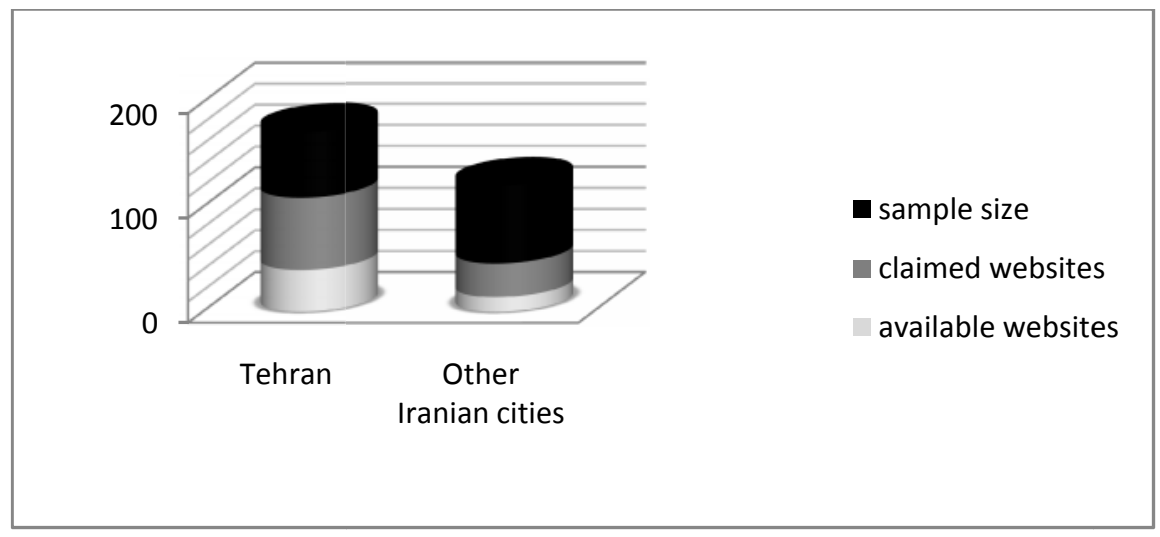

Figure 2. Internet presence status of analyzed travel agencies

As conducted from the previous analysis it was expected that the performance of Iranian travel agencies would be stronger in product information than other categories. Only $37.7 \%$ of the criteria in this category existed in the websites, which is related to the primary criteria of product introduction. In fact it is safe to say that Iranian travel agencies have only created an online catalogue, and for further improvement, they must pay more attention to other criteria.

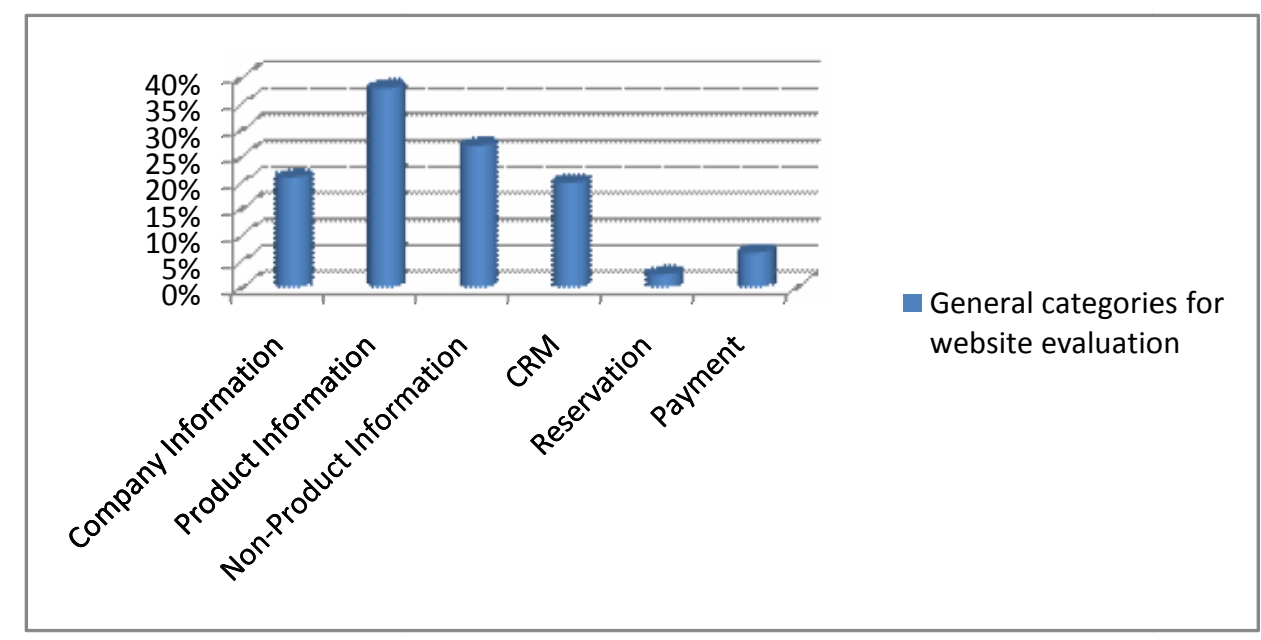

Figure 3. Evaluated results of general categories for website evaluation

As you can see from the results in figure 3, the weakest part of Iranian travel agencies performances, are related to reservation and payment which are $2.5 \%$ and $6.7 \%$ in order. 
International Journal of Advanced Information Technology (IJAIT) Vol. 2, No.6, December 2012

According to Jellasi [22] in order to be successful in market, organizations should be able to capture the value created for the customer in form of money.

Unfortunately the evaluated travel agencies were much weaker in value capturing than value creating and this is due to lack of reservation and e-payment facilities in their websites.

\section{Conclusion}

In the beginning of this research the criteria for travel agencies website evaluation were chosen, and the websites were evaluated accordingly in two sections, Tehran (the capital of Iran), and other cities. The results showed that, based on the levels of website presence [24], most Iranian travel agencies are in level 1 , and also that the majority of travel agencies managers do not have a proper understanding, how to enter the web, because without implementing the essential primary features in the lower levels, they have started implementing more complex features.

In this research the stage of Iranian travel agencies web presence was investigated. Further work can be done on establishing the success and failure factors of the travel agencies moves towards entering the web.

\section{REFERENCES}

[1] Dimitrios Buhalis, Soo Hyun Jun, (2011), E-Tourism, Contemporary Tourism Reviews, Goodfellow Publishers Limited, pp. 1-38.

[2] Http://media.unwto.org/en/press-release/2011-10-11/international-tourists-hit-18-billion-2030, retrieve on 04/01/2012 at 10:56 pm.

[3] Forrester, 1999, Report January, (1999), available at www.forester.com.

[4] Http://internetworldstats.com/stats5.htm, retrieved on 04/01/2012 at 10:50 pm.

[5] Wen-Chih Chiou, Chin-Chao Lin, Chyuan Perng, (2010), A strategic framework for website evaluation based on a review of the literature from 1995-2006, Journal of Information \& Management, Vol. 47, pp. 282-290.

[6] Wen-Chih Chiou, Chin-Chao Lin, Chyuan Perng, (2011), Case study: A strategic website evaluation of online travel agencies, Journal of Tourism Management, pp. 1-11.

[7] Xiaobing Yu, Shunsheng Guo, Jun Guo, Xiaorong uang, (2011), Rank B2C e-commerce websites in e-alliance based on AHP and fuzzy TOPSIS, Journal of Expert System with Application, 38 , pp. 3550-3557.

[8] Xiuli Cao, Yanhua Liu, Bing Shen, Min Wang, (2009), Research on Evaluation of B to C Ecommerce Website Based on AHP and Grey Evaluation, Second International Symposium on Electronic Commerce and Security, IEEE, pp. 405-408.

[9] Soyoung Kim, Lesli Stoel, (2004), Apparel retailers: website quality dimensions and satisfaction.

[10] Alastair G. Smith, (2001), Applying evaluation criteria to New Zealand government websites, International Journal of Information Management, Vol. 21, pp.137-149.

[11] Nocolae-george dragulanescu, (2002), Website quality evaluation criteria and tools, international Journal of Information \& Library, Vol. 34, pp. 247-254.

[12] Layla Hasan, Emad Abuelrub, (2011), Assessing the quality of web sites, Applied Computing and Informatics, Vol. 9, pp.11-29.

[13] R. Ufuk Bilsel, Gulcin Buyukozkan, Da Ruan, (2006), A Fuzzy Preference-Ranking for a Quality Evaluation of Hospital Websites, International journal of Intelligent Systems, Vol. 21, pp. 11811197.

[14] Wei-Hsi Hung, Robert J McQueen, (2006), Developing an Evaluation Instrument for e-Commerce Websites from the First-Time Buyer's Viewpoint, 2006, Electronic Journal of Information Systems Evaluation, Vol. 7, No. 1, pp. 31-42.

[15] Bindu Madhuri .Ch, Padmaja.M, Srinivasa Rao.T, Anand Chandulal.J, (2010), Evaluating Web Site based on Grey Clustering Theory combined with AHP , International Journal of Engineering and Technology, Vol. 2 Vol. 2, pp.71-76. 
International Journal of Advanced Information Technology (IJAIT) Vol. 2, No.6, December 2012

[16] John Paynter, Suwannee Satitkit, (2001), An evaluation of travel agent web sites, University of Auckland press.

[17] Chung, T. and Law, R., (2003). Developing a performance indicator for hotel websites, International Journal of Hospitality Management, Vol. 22, No. 1, pp. 119-125.

[18] Park C (2003), A content analysis of travel agency websites in Korea, Asia Pacific Journal of Tourism Research, Vol. 7, No. 1, pp. 11-18.

[19] Law, R., \& Leung, R., (2000). A study of airlines' online reservation services on the Internet, Journal of Travel Research, Vol. 39, No. 2, pp. 202-211.

[20] Maswera, T., Dawson, R., Edwars, J., (2007), E-commerce adoption of travel and tourism organization in South Africa, Kenya, Zimbabwe and Uganda, Telematics and Informatics, pp. 1-14.

[21] Hen, J.H., Mills, J. E., (2006), Zero Acquaintance Benchmarking at Travel Destination Websites: What is the First Impression that National Tourism Organization Try to Make?, International Journal of Tourism Reasearch, Vol. 8, pp. 405-430.

[22] Jelassi. Tawfik, Enders. Albrecht, (2004), Strategies for e-business: creating value through electronic and mobile commerce, First edition.

[23] Saddad, Gh., (2009), A Study of E-commerce Applications Adoption in Iranian Tourist Organizations , Tarbiat Modares University, Faculty of Engineering, Department of Industrial Engineering, Lulea University of Technology, Division of Industrial Marketing and E-commerce.

[24] Teo, T. and Pian, Y., (2003), A contingency perspective on internet adoption and competitive advantage, European Journal of Information System, Vol. 12, No. 2, pp. 78-91.

\section{Author}

Raika sadeghein has a master's degree in Information Technology from K.N.Toosi University of Technology in Iran and she has also earned a bachelor's degree in computer hardware engineering from Azad University. Her research interests are tourism, e-commerce, technology readiness and adoption and marketing.

Dr. Farid Khoshalhan is an associated Professor in Industrial Engineering and Information Technology at Faculty of Industrial Engineering, K.N.Toosi University of Technology, Tehran-IRAN. His research and client work has focused on decision making, evolutionary algorithms, performance and productivity management and trust and adoption in ecommerce. Dr. Khoshalhan earned bachelor's degree in industrial technology from Iran University of Science and Technology, a master's and PhD in industrial engineering from Tarbiat Modarres University in IRAN. Tell:+9821-88674843

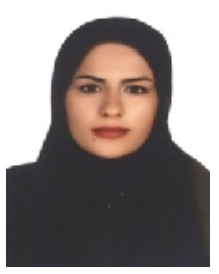

Sajad Homayoun has a master's degree in Information Technology form K. N. Toosi University of Technology in Iran and he also earned a bachelor's degree in computer software engineering. His research interests are data mining, evolutionary algorithms, elearning and website evaluation and development.
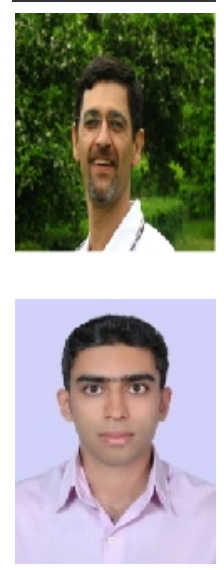